\title{
Immuno-virologic outcomes and immuno- virologic discordance among adults alive and on anti-retroviral therapy at 12 months in Nigeria
}

Chuka J Anude ${ }^{1,2^{*}}$, Emeka Eze ${ }^{3}$, Henry C Onyegbutulem ${ }^{4}$, Man Charurat ${ }^{1}$, Mary-Ann Etiebet ${ }^{1}$, Samuel Ajayi ${ }^{5}$, Patrick Dakum ${ }^{1,6}$, Oluyemisi Akinwande ${ }^{6}$, Chris Beyrer ${ }^{2}$, Alash'le Abimiku ${ }^{1}$ and William Blattner ${ }^{1}$

\begin{abstract}
Background: Predictors of immuno-virologic outcomes and discordance and their associations with clinical, demographic, socio-economic and behavioral risk factors are not well described in Nigeria since HIV viral load testing is not routinely offered in public HIV treatment programs.

Methods: The HACART study was a multi-center observational clinic-based cohort study of 2585 adults who started HAART between April 2008 and February 2009. A total of 628 patients were randomly selected at 12 months for immuno-virologic analyses.

Results: Virologic suppression rate $(<400$ copies $/ \mathrm{ml})$ was $76.7 \%$, immunologic recovery rate (CD4 change from baseline $\geq 50 \mathrm{cells} / \mathrm{mm}^{3}$ ) was $77.4 \%$ and immuno-virologic discordance rate was $33 \%$. In multivariate logistic regression, virologic failure was associated with age $<30$ years (OR 1.79; 95\% Cl: 1.17-2.67, $p=0.03$ ), anemia (Hemoglobin < $10 \mathrm{~g} / \mathrm{dl}$ ) (OR 1.71; 95\% Cl: 1.22-2.61, $p=0.03$ ), poor adherence (OR 3.82; 95\% Cl: 2.17-5.97, $p=0.001)$, and post-secondary education (OR 0.60; $95 \% \mathrm{Cl}: 0.30-0.86, p=0.02$ ). Immunologic failure was associated with male gender (OR 1.46; 95\% Cl: 1.04-2.45, $p=0.04$ ), and age $<30$ years (OR 1.50; 95\% Cl: 1.11-2.39, $p=0.03$ ). Virologic failure with immunologic success ( $\left.\mathrm{VL}^{-} / \mathrm{CD}^{+}\right)$was associated with anemia (OR 1.80; 95\% Cl: 1.13-2.88, $p=0.03$ ), poor adherence (OR 3.90; 95\% Cl: 1.92-8.24, $p=0.001$ ), and post-secondary education (OR 0.40; 95\% Cl: 0.22-0.68, $p=0.005$ ).

Conclusions: Although favorable immuno-virologic outcomes could be achieved in this large ART program, immuno-virologic discordance was observed in a third of the patients. Focusing on intensified treatment preparation and adherence, young patients, males, persons with low educational status and most importantly baseline anemia assessment and management may help address predictors of poor immuno-virologic outcomes, and improve overall HIV program impact. Viral load testing in addition to the CD4 testing should be considered to identify, characterize and address negative immuno-virologic outcomes and discordance.
\end{abstract}

Keywords: Immuno-virologic outcomes, Immuno-virologic discordance, Anemia, Treatment failure, Sub-Saharan Africa, Nigeria, PEPFAR, Anti-retroviral therapy, Viral load testing

\footnotetext{
* Correspondence: canude@jhsph.edu

'Institute of Human Virology, University of Maryland School of Medicine, Baltimore, Maryland, USA

${ }^{2}$ Johns Hopkins University Bloomberg School of Public Health, Baltimore, Maryland, USA

Full list of author information is available at the end of the article
} 


\section{Background}

Every HIV treatment program is confronted with the triple challenge of addressing gaps in coverage (access), retention in care and improving treatment outcomes. With HIV treatment access now a reality in most of sub-Saharan Africa (SSA), attention and concerns have rightly shifted to issues of retention in care, negative treatment outcomes, HIV drug resistance and treatment failures [1-4]. Treatment failure is known to result in greater treatment complexity and cost and in worsening morbidity and mortality rates among treated persons $[5,6]$. In resource-constrained settings, the World Health Organization (WHO) currently does not recommend routine HIV viral load (VL) testing, in part due to the cost and complex infrastructure needed for reliable results [5,7] but proposes the use of clinical and CD4+ lymphocyte-based criteria to guide treatment decision.

By the time most patients are diagnosed with immunologic failure (using 6 monthly CD4 cell counts) or clinical failure (by clinical history / examination or presence of new opportunistic infections), multiple drug resistance mutations may have developed compromising and complicating future drug treatment options [8,9]. Furthermore, there are groups of patients where viral replication is suppressed appropriately but without immunologic recovery. On the other hand, there are patients with immunologic recovery but without sustained viral load suppression. Thus, immuno-virologic discordance occurs when viral load test results used to assess virologic failure do not correspond to expected CD4 cell count results used to assess immunologic failure, and this discordance is associated with poor clinical outcomes.

Previous immuno-virologic outcomes studies in Africa [10-12] have been done in programs that commonly use Stavudine (d4T)-containing or Zidovudine (AZT)containing first line highly active antiretroviral therapy (HAART). Little is known about immuno-virologic outcomes in US-government funded African public programs that do not perform routine viral load testing, but predominantly uses Tenofovir (TDF), an ARV with a different potency, safety, and resistance profile as part of a first line drug regimen. We sought to identify predictors of immuno-virologic outcomes and discordance among adults on ART who were still alive at 12 months.

\section{Methods}

\section{Ethics statement}

The study was reviewed and approved from all the Institutional Review Boards (IRB) of all three index hospitals in Nigeria, the Nigerian National Health Research Ethics Committee (NHREC), and the University of Maryland School of Medicine, Baltimore, Maryland, USA. Written informed consent was obtained from all the study participants after counseling and introduction of the study.

The HIV AIDS Care and Anti-Retroviral Therapy (HACART) study was a large multi-center observational clinic-based cohort study that described the predictors of loss to follow-up, immuno-virologic outcomes, immuno-virologic discordance and sub-optimal drug adherence within the AIDS Care and Treatment in Nigeria (ACTION) project. Funded by the U.S. Centers for Disease Control and Prevention Global AIDS Program (CDC GAP), the ACTION project is a tripartite partnership between the Institute of Human Virology of the University Of Maryland School Of Medicine, the Institute of Human Virology Nigeria, and the Nigerian Federal and State Ministries of Health.

A cohort of 2585 initially ART naïve adults who started HAART between April 2008 and February 2009 were followed up for 12 months in three representative government hospitals in Nigeria: University of Abuja Teaching Hospital, Abuja (UATH), University of Benin Teaching Hospital, Benin (UBTH) and Asokoro District Hospital, Asokoro, Abuja (ADH). These sites consisted of a mix of tertiary (UATH and UBTH) and secondary $(\mathrm{ADH})$ health facilities located in different regions of the country and serving different populations to increase generalizability. With $805(31 \%)$ lost to follow-up, a total of 628 out of the 1780 patients alive and active on the program at 12 months were randomly selected for indepth interviews and laboratory work-up with detailed virologic and immunologic testing (Figure 1). There were no significant demographic and clinical differences between study patients at the 12 month time period and all the other patients alive and active at that 12 month time period (data not shown).

\section{Study design and patient management}

Patients had their information recorded at baseline, were enrolled into ART care and followed up with prospective data abstracted from the medical records. Additional data not available at baseline was obtained at the 12-month visit. Blood work included HIV PCR RNA testing, CD4 cell count test, complete blood count and chemistry. Diagnosis of virologic and immunologic failure was made based on the results of the laboratory testing.

Before commencement of ART most patients underwent detailed history, physical examination, treatment preparation, HIV disclosure counseling, symptomatic screening for tuberculosis and laboratory work-up. Laboratory tests done at baseline included CD4 cell count, complete blood count, liver function tests and serum creatinine test. There were some missing laboratory results due to laboratory reagent shortage, or administrative errors. Cotrimoxazole was provided to eligible patients whose CD4 counts were less than 200 cells $/ \mathrm{ml}$. 


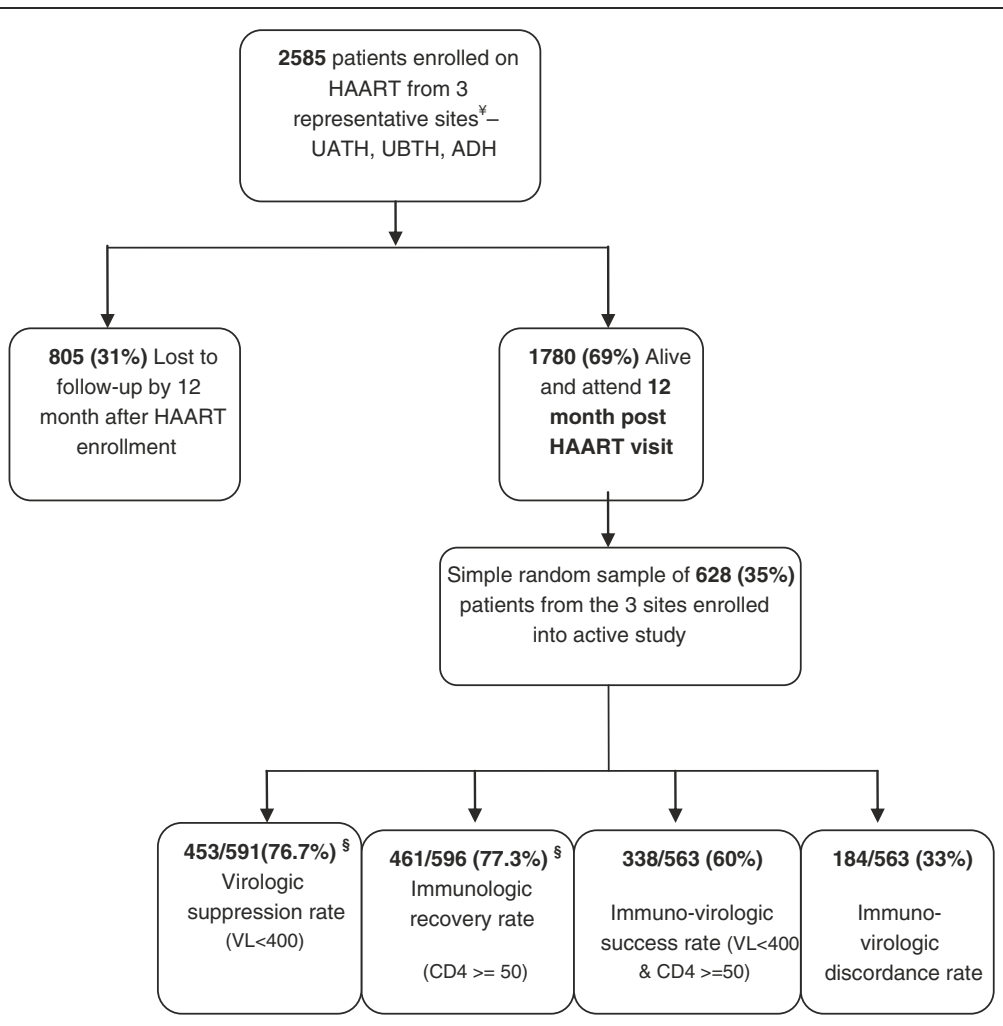

Figure 1 Flow chart of Nigerian adults on ART recruited at 12 months and their 12-month outcomes.

HAART was provided if patients satisfied an immunologic criteria (CD4 less than 200 cells/ml irrespective of WHO staging) ${ }^{\mathrm{a}}$ or a clinical criteria (WHO stage 3 or 4 irrespective of $\mathrm{CD} 4$ cell count level). The choice of HAART combination was both guided by national treatment protocols and the discretion of the attending physician but generally consisted of one of three first line regimens (Tenofovir (TDF) + Lamivudine (3TC) + Nevirapine (NVP) / Efavirenz (EFV), Zidovudine (AZT) + $3 \mathrm{TC}+\mathrm{NVP} / \mathrm{EFV}$, Stavudine (d4T) + 3TC + NVP / EFV. Patients who were anemic were preferably given TDF instead of AZT and persons who were co-infected with tuberculosis were also preferably given EFV instead of NVP. EFV was generally avoided in women of childbearing age especially if they were not adherent to double contraception methods. A three months' supply of drugs were provided (after an initial one month supply) with three monthly refill follow-ups and six monthly CD4 testing done together with adherence counseling sessions according to the national ART guidelines. Patients who default from scheduled clinic and pharmacy refill visits were followed-up by the home-based care team.

\section{Data collection}

Standardized patient management and monitoring forms and interviews were used to capture detailed clinical, laboratory and demographic data, some of which were extracted from the CAREWare health information management system. Adherence was measured objectively by pharmacy refill records and subjectively by self-report. Residential distance from treatment sites to closest known town was determined in kilometers using the official Nigerian national road distance calculator and a unique online Nigerian distance tool at Globefeed.com (http://distancecalculator.globefeed.com/ Nigeria_Distance_Calculator.asp). Since there were no validated data on socio-economic (SES) classifications in Nigeria, a quintile of class $1-5$ was developed based on socio-economic scores calculated using 4 indicators commonly used in social epidemiology studies (highest educational achievement, employment status, household size, and monthly household income in naira (1 US $\$=150$ Nigerian Naira).

\section{Outcome definition and ascertainment}

Virologic failure $\left(\mathrm{VL}^{-}\right)$was defined as a HIV RNA level of equal or more than 400 copies / ml at the 12 month visit in line with local laboratory assay detection limits (viral load testing was done by quantitative polymerase chain reaction (PCR) for HIV-1 RNA in human plasma using Roche Amplicor version 1.5; Roche Diagnostics, Basal, Switzerland) and national treatment guidelines in Nigeria. Even though baseline HIV RNA levels were not done, it was expected that with adherence to potent 
Table 1 Baseline, clinical and individual level characteristics of active adult study participants in Nigerian ART program ( $n=628$ )

Characteristics

\begin{tabular}{|c|c|c|c|c|c|}
\hline & $\begin{array}{l}\text { Number of participants } \\
\text { (\% of total) }\end{array}$ & UATH (site \%) & ADH (site \%) & UBTH (site \%) & $\begin{array}{c}\text { p- } \\
\text { value }\end{array}$ \\
\hline Gender & & & & & 0.31 \\
\hline Female & $400(63.7 \%)$ & $128(59.8 \%)$ & $110(67.1 \%)$ & $162(64.8 \%)$ & \\
\hline Male & $228(36.3 \%)$ & $86(40.2 \%)$ & $54(32.9 \%)$ & $88(35.2 \%)$ & \\
\hline \multicolumn{6}{|l|}{ Age at HAART Initiation (years) } \\
\hline Median (Inter-quartile range) & $35(30-41)$ & $34(29-41)$ & $34(29-38)$ & $36(30-45)$ & 0.001 \\
\hline$<30$ & $190(30.3 \%)$ & $70(32.7 \%)$ & $55(33.5 \%)$ & $65(26 \%)$ & \\
\hline 31 to 40 & $271(43.1 \%)$ & $89(41.6 \%)$ & $84(51.2 \%)$ & $98(39.2 \%)$ & \\
\hline 41 to 50 & $120(19.1 \%)$ & $43(20.1 \%)$ & $20(12.2 \%)$ & $57(22.8 \%)$ & \\
\hline$>51$ & $47(7.5 \%)$ & $12(5.6 \%)$ & $5(3.1 \%)$ & $30(12 \%)$ & \\
\hline Marital Status & & & & & 0.001 \\
\hline Single & $146(23.2 \%)$ & $43(20.1 \%)$ & 47 (28.7\%) & $56(22.4 \%)$ & \\
\hline Married / Cohabiting & $359(57.2 \%)$ & $136(63.6 \%)$ & $88(53.7 \%)$ & $135(54 \%)$ & \\
\hline Separated & $45(7.2 \%)$ & $5(2.3 \%)$ & $9(5.5 \%)$ & $31(12.4 \%)$ & \\
\hline Divorced / Widowed & $78(12.4 \%)$ & $30(14 \%)$ & $20(12.2 \%)$ & $28(11.2 \%)$ & \\
\hline Currently married & & & & & 0.07 \\
\hline Yes & $359(57.2 \%)$ & $136(63.6 \%)$ & $88(53.7 \%)$ & $135(54 \%)$ & \\
\hline No & $269(42.8 \%)$ & $78(36.4 \%)$ & $76(46.3 \%)$ & $115(46 \%)$ & \\
\hline Residential Distance (in kilometers) & & & & & 0.001 \\
\hline Median (inter-quartile range) & $25(10-80)$ & $46.5(20-90)$ & $23(15-30)$ & $10(5-130)$ & \\
\hline$<50$ & $402(64 \%)$ & $109(50.9 \%)$ & $133(81.1 \%)$ & $160(64 \%)$ & \\
\hline 51 to100 & $80(12.7 \%)$ & $54(25.2 \%)$ & $16(9.8 \%)$ & $10(4 \%)$ & \\
\hline 101 to 200 & $120(19.1 \%)$ & $44(20.6 \%)$ & $6(3.7 \%)$ & $70(28 \%)$ & \\
\hline$>200$ & $26(4.1 \%)$ & $7(3.3 \%)$ & $9(5.5 \%)$ & $10(4 \%)$ & \\
\hline HIV disclosure & & & & & 0.34 \\
\hline Yes & $595(94.7 \%)$ & $204(95.3 \%)$ & $158(96.3 \%)$ & $233(93.2 \%)$ & \\
\hline No & $33(5.3 \%)$ & $10(4.7 \%)$ & $6(3.7 \%)$ & $17(6.8 \%)$ & \\
\hline Tuberculosis History & & & & & 0.001 \\
\hline Yes & $90(14.3 \%)$ & $18(8.4 \%)$ & $37(22.6 \%)$ & $35(14 \%)$ & \\
\hline No & $538(85.7 \%)$ & $196(91.6 \%)$ & $127(77.4 \%)$ & $215(86 \%)$ & \\
\hline Baseline CD4 cell count $(n=613)$ & & & & & 0.001 \\
\hline Median (inter-quartile range) & $142(85-223)$ & $117(72-175)$ & $187(111-266)$ & $150(88-241)$ & \\
\hline$<50$ & $88(14.4 \%)$ & $42(19.8 \%)$ & $15(9.3 \%)$ & $31(13 \%)$ & \\
\hline 50 and $<200$ & $336(54.8 \%)$ & $143(67.5 \%)$ & $74(45.7 \%)$ & $119(49.8 \%)$ & \\
\hline 200 and $<350$ & $155(25.3 \%)$ & $19(9 \%)$ & $54(33.3 \%)$ & $82(34.3 \%)$ & \\
\hline 350 and $<500$ & $24(3.9 \%)$ & $4(1.9 \%)$ & $16(9.9 \%)$ & $4(1.7 \%)$ & \\
\hline$>=500$ & $10(1.6 \%)$ & $4(1.9 \%)$ & $3(1.9 \%)$ & $3(1.3 \%)$ & \\
\hline Baseline Hemoglobin $(g / d l)(n=546)$ & & & & & 0.001 \\
\hline Median (inter-quartile range) & $10.9(9.3-12.4)$ & $10.5(8.8-11.9)$ & $12.1(10.8-13.9)$ & $10.3(8.9-11.6)$ & \\
\hline$>=10$ & $354(64.9 \%)$ & $107(60.1 \%)$ & $131(84 \%)$ & $116(54.7 \%)$ & \\
\hline$>=8$ and $<10$ (Grade 1 anemia) & $141(25.8 \%)$ & $57(32 \%)$ & $17(10.9 \%)$ & $67(31.6 \%)$ & \\
\hline$>=7$ and $<8$ (Grade 2 anemia) & $33(6.0 \%)$ & $7(3.9 \%)$ & $7(4.5 \%)$ & $19(9 \%)$ & \\
\hline
\end{tabular}


Table 1 Baseline, clinical and individual level characteristics of active adult study participants in Nigerian ART program ( $\mathrm{n}=\mathbf{6 2 8})$ (Continued)

$>=6.5$ and $<7$ (Grade 3 anemia)
$<6.5$ (Grade 4 anemia)
Baseline anemia (Hemoglobin $<\mathbf{1 0} \mathbf{~} \mathbf{~} \mathbf{d l}$ )
$(\mathbf{n}=\mathbf{5 4 6}$ )
Yes
No

Antiretroviral drug regimen at baseline

ZDV / 3TC / NVP or EFV

D4T / 3TC / NVP or EFV

TDF / 3TC of FTC / NVP or EFV

Baseline Functionality

Working (70-100\%)

Ambulatory (50-70\%)

Bedridden $(<50 \%)$

\section{Reason for ART eligibility}

CD4 cell count $<200$

CD4 cell count $<350$ and WHO Stage 3

WHO Stage 4

Other (PMTCT plus, etc.)

Drug adherence by pharmacy refill record calculated over 12 months

$>=95 \%$

$<95 \%$

Drug adherence by self-report at 12 months

$>=95 \%$

$<95 \%$

Virologic suppression $(<400$ copies) $(n=591)$

Yes

No

Immunologic recovery (CD4 cell change $>=50$ )

$(n=596)$

Yes

No

\section{Employment status}

Employed

Unemployed

Retired

Student

Highest educational achievement

No formal education

Primary education

\author{
$7(1.3 \%)$
}

$11(2.0 \%)$

192 (35.2\%)

$354(64.8 \%)$

257 (40.9\%)

50 (8.0\%)

$321(51.1 \%)$

$479(78 \%)$

$123(20 \%)$

$12(2 \%)$

$$
\begin{gathered}
438(72.2 \%) \\
144(23.8 \%) \\
18(3 \%) \\
6(1 \%)
\end{gathered}
$$

576 (91.7\%)

$52(8.3 \%)$

\section{$544(86.6 \%)$}

84 (13.4\%)

453 (76.7\%)

138 (23.3\%)

$$
\begin{gathered}
461(77.4 \%) \\
135(22.6 \%) \\
524(83.4 \%) \\
99(15.8 \%) \\
1(0.2 \%) \\
4(0.6 \%)
\end{gathered}
$$

301 (47.9\%)

136 (21.7\%)

$3(1.7 \%)$

$4(2.3 \%)$

71 (39.9\%)

107 (60.1\%)

25 (16\%)

131 (84\%)

96 (45.3\%)

116 (54.7\%)

$$
\begin{gathered}
58(27.1 \%) \\
15(7 \%) \\
141(65.9 \%) \\
170(81.3 \%) \\
38(18.2 \%) \\
1(\%)
\end{gathered}
$$

76 (46.3\%)

10 (6.1\%)

78 (47.6\%)

$4(1.9 \%)$

$6(2.8 \%)$

188 (90.4\%)

$14(6.7 \%)$

1 (0.5\%)

5 (2.4\%)

(2)

202 (94.4\%)

12 (5.6\%)

137 (83.5\%)

27 (16.5\%)

\section{$193(90.2 \%)$}

21 (9.8\%)

135 (82.3\%)

29 (17.7\%)

$167(78.4 \%)$

$46(21.6 \%)$

94 (71.2\%)

38 (28.8\%)

178 (84.4\%)

33 (15.6\%)

$110(74.3 \%)$

38 (25.7\%)

183 (85.5\%)

116 (70.7\%)

27 (12.6\%)

$1(0.5)$

$3(1.4 \%)$

92 (43\%)

54 (25.2\%)

$54(22 \%)$
0.001

0.001

0.001

0.08

0.001

0.001

0.001
237 (94.8\%)

13 (5.2\%)

$173(73 \%)$

64 (27\%)

225 (90\%)

192 (78\%)

24 (9.6\%)

$0(0 \%)$

1 (0.4\%)

129 (51.6\%)

60 (24\%) 
Table 1 Baseline, clinical and individual level characteristics of active adult study participants in Nigerian ART program ( $\mathrm{n}=\mathbf{6 2 8}$ ) (Continued)

\begin{tabular}{|c|c|c|c|c|c|}
\hline Secondary education & $34(5.4 \%)$ & $14(6.5 \%)$ & $17(10.4 \%)$ & $3(1.2 \%)$ & \\
\hline $\begin{array}{l}\text { Post-secondary / Tertiary / Advanced Education } \\
\text { (M.Sc., Ph.D.) }\end{array}$ & $157(25 \%)$ & $54(25.3 \%)$ & 45 (27.4\%) & $58(23.2 \%)$ & \\
\hline Socio-economic class & & & & & 0.001 \\
\hline Class 1 & $23(3.7 \%)$ & $13(6.1 \%)$ & $2(1.2 \%)$ & $8(3.2 \%)$ & \\
\hline Class 2 & 99 (15.6\%) & $27(12.6 \%)$ & $22(13.4 \%)$ & $50(20 \%)$ & \\
\hline Class 3 & $276(44 \%)$ & 79 (36.9\%) & $63(38.4 \%)$ & $134(53.6 \%)$ & \\
\hline Class 4 & $207(33 \%)$ & $88(41.1 \%)$ & $66(40.3 \%)$ & $53(21.2 \%)$ & \\
\hline Class 5 & $23(3.7 \%)$ & $7(3.3 \%)$ & $11(6.7 \%)$ & $5(2 \%)$ & \\
\hline Current smoker & & & & & 0.65 \\
\hline Yes & $11(1.8 \%)$ & $5(2.3 \%)$ & $3(1.8 \%)$ & $3(1.2 \%)$ & \\
\hline No & $617(98.2 \%)$ & 209 (97.7\%) & $161(98.2 \%)$ & $247(98.8 \%)$ & \\
\hline Current drug user & & & & & 0.24 \\
\hline Yes & $1(0.2 \%)$ & $0(0 \%)$ & $1(0.6 \%)$ & $0(0 \%)$ & \\
\hline No & $627(99.8 \%)$ & $214(100 \%)$ & $163(99.4 \%)$ & $250(100 \%)$ & \\
\hline Current alcohol user & & & & & 0.001 \\
\hline Yes & $53(8.4 \%)$ & $2(0.9 \%)$ & $29(17.7 \%)$ & $22(8.8 \%$ & \\
\hline No & $575(91.6 \%)$ & $212(99.1 \%)$ & $135(82.3 \%)$ & $228(91.2 \%)$ & \\
\hline Current herbal drug user & & & & & 0.03 \\
\hline Yes & $20(3.2 \%)$ & $3(1.4 \%)$ & $10(6.1 \%)$ & $7(2.8 \%)$ & \\
\hline No & $608(96.8 \%)$ & 211 (98.6\%) & 154 (93.9\%) & 243 (7.2\%) & \\
\hline
\end{tabular}

Categorical variables expressed as $n$ (\%) and continuous variables almost expressed as median (inter-quartile range).

${ }^{\S} \mathrm{p}$-values comparing study participant variables across the three study sites calculated from Kruskal-Wallis test statistic for continuous variables and Pearson $\chi^{2}$ test statistic for categorical variables.

HAART regimen, viral load levels would generally be undetectable $(<400$ copies/ ml) by 12 months. Fresh samples from UBTH were processed and tested on site and fresh samples from AUTH and ADH were processed and tested at the National IHV reference laboratory onsite at $\mathrm{ADH}$. Immunologic failure $\left(\mathrm{CD} 4^{-}\right)$was defined with the WHO definition of "fall in CD4 count to baseline (preHAART) or below baseline levels (zero CD4 cell change)" or failure of CD4 cell to improve by at least 50 cells at 12 months $[5,13]$. A CD4 change of $\geq 50$ cells from baseline was regarded as a sign of progressive immune recovery and has been used in other studies [14,15]. The CD4 cell count determination was done using Cyflow counter (Cyflow counter, Partec, GmbH, Gorlitz, Germany). Immuno-virologic failure is the combination of immunologic and virologic failure with virologic failure generally seen to precede immunologic failure. In this study, immuno-virologic discordance is said to occur when virologic failure is not followed by immunologic failure or when virologic success is not accompanied by immunologic success. Immuno-virologic discordance was divided into: virologic failure with immunologic success $\left(\mathrm{VL}^{-} / \mathrm{CD} 4^{+}\right)$and immunologic failure with virologic success $\left(\mathrm{VL}^{+} / \mathrm{CD} 4^{-}\right)$.

\section{Statistical analysis}

Predictors of interest (age, marital status, residential distance, baseline CD4 cell count, employment, tuberculosis history, regimen type, HIV disclosure, drug adherence and educational achievement) were categorized for data analysis. Hemoglobin was categorized either as a dichotomous variable using hemoglobin cut-off of $10 \mathrm{~g} / \mathrm{dl}$ for anemia. Kruskal Wallis and Pearson $\chi^{2}$ tests were used to compare continuous and categorical variables respectively by site and outcome. Univariate and multivariate logistic regression was used to model the association between potential clinical, demographic, behavioral and socio-economic predictors on virologic and immunologic outcomes. To adjust for confounding, predictors were not included in the multivariable model if they yielded a univariate $\mathrm{p}$-value of $\geq 0.2$ according to the methods described by Maldonado and Greenland $[16,17]$. Covariates that were a priori known to be associated with the outcome of interest were forced into the model for face validity regardless of level of significance. Covariates in the final model were selected by step-wise backward selection procedure. Model goodness of fit was done by Hosmer-Lemeshow goodness of fit test. 
Table 2 Comparison of baseline characteristics of Nigerian adults lost-to-follow-up and participating in the HACART study at 12 months

\begin{tabular}{|c|c|c|c|}
\hline Characteristics & $\begin{array}{l}\text { Lost-To-Follow-Up } \\
\qquad(\mathrm{n}=\mathbf{8 0 5})\end{array}$ & $\begin{array}{l}\text { Study participants } \\
\qquad(\mathrm{n}=628)\end{array}$ & p-value ${ }^{\S}$ \\
\hline Gender & & & 0.99 \\
\hline Female & $513(63.7 \%)$ & $400(63.7 \%)$ & \\
\hline Male & $292(36.3 \%)$ & $228(36.3 \%)$ & \\
\hline Age at HAART Initiation (years) & & & 0.04 \\
\hline Median (Inter-quartile range) & $33(28-40)$ & $35(30-41)$ & \\
\hline$<30$ & $304(37.7 \%)$ & $190(30.3 \%)$ & \\
\hline 31 to 40 & $306(38 \%)$ & $271(43.1 \%)$ & \\
\hline 41 to 50 & $139(17.3 \%)$ & $120(19.1 \%)$ & \\
\hline$>50$ & $56(7 \%)$ & $47(7.5 \%)$ & \\
\hline Marital Status $(\mathrm{n}=2398)^{\ddagger}$ & & & 0.15 \\
\hline Single & $184(24.7 \%)$ & $146(23.2 \%)$ & \\
\hline Married / Cohabiting & $449(60.4 \%)$ & $359(57.2 \%)$ & \\
\hline Separated & $40(5.4 \%)$ & $45(7.2 \%)$ & \\
\hline Divorced / Widowed & $71(9.5 \%)$ & $78(12.4 \%)$ & \\
\hline Currently married $(n=2398)$ & & & 0.23 \\
\hline Yes & $449(60.3 \%)$ & $359(57.2 \%)$ & \\
\hline No & 295 (39.7\%) & $269(42.8 \%)$ & \\
\hline Residential Distance (in kilometers) $(n=2295)^{\ddagger}$ & & & 0.001 \\
\hline Median (inter-quartile range) & $15(10-75)$ & $25(10-80)$ & \\
\hline$<50$ & $486(60.4 \%)$ & $402(64 \%)$ & \\
\hline 51 and $<100$ & $134(16.7 \%)$ & $80(12.7 \%)$ & \\
\hline 101 and $<200$ & $100(12.4 \%)$ & $120(19.1 \%)$ & \\
\hline$>=200$ & $13(1.8 \%)$ & $26(4.1 \%)$ & \\
\hline HIV disclosure $(n=2082)^{\ddagger}$ & & & 0.28 \\
\hline Yes & $481(93.2 \%)$ & $595(94.7 \%)$ & \\
\hline No & $35(6.8 \%)$ & $33(5.3 \%)$ & \\
\hline Tuberculosis History $(n=2025)^{\ddagger}$ & & & 0.76 \\
\hline Yes & $72(13.7 \%)$ & $90(14.3 \%)$ & \\
\hline No & $453(86.3 \%)$ & $538(85.7 \%)$ & \\
\hline Baseline CD4 count $(n=2033)^{\ddagger}$ & & & 0.001 \\
\hline Median (inter-quartile range) & $119(54-218)$ & $142(85-223)$ & \\
\hline$<50$ & $137(22.6 \%)$ & $88(14.4 \%)$ & \\
\hline$>=50$ and $<200$ & $301(49.7 \%)$ & $336(54.8 \%)$ & \\
\hline$>=200$ and $<350$ & $99(16.3 \%)$ & $155(25.3 \%)$ & \\
\hline$>=350$ and $<500$ & $29(4.8 \%)$ & $24(3.9 \%)$ & \\
\hline$>=500$ & $40(6.6 \%)$ & $10(1.6 \%)$ & \\
\hline Baseline Hemoglobin $(g / d l)(n-1606)^{\neq}$ & & & 0.001 \\
\hline Median (inter-quartile range) & $9.9(8-11.5)$ & $10.9(9.3-12.4)$ & \\
\hline$>=10$ & $228(48.6 \%)$ & $354(64.8 \%)$ & \\
\hline$>=8$ and $<10$ (Grade 1 anemia) & $127(27.1 \%)$ & $141(25.8 \%)$ & \\
\hline$>=7$ and $<8$ (Grade 2 anemia) & $42(9 \%)$ & $33(6 \%)$ & \\
\hline
\end{tabular}


Table 2 Comparison of baseline characteristics of Nigerian adults lost-to-follow-up and participating in the HACART study at 12 months (Continued)

\begin{tabular}{lcc}
\hline$>=6.5$ and $<7$ (Grade 3 anemia) & $14(3 \%)$ & $7(1.3 \%)$ \\
$<6.5$ (Grade 4 anemia) & $58(12.4 \%)$ & $11(2 \%)$ \\
Baseline anemia (Hemoglobin $<\mathbf{1 0} \mathbf{g} \mathbf{d l})$ & & $192(35.2 \%)$ \\
Yes & $241(51.4 \%)$ & $354(64.8 \%)$ \\
No & $228(48.6 \%)$ & \\
Antiretroviral drug regimen at baseline & & $275(40.9 \%)$ \\
ZDV / 3TC / NVP or EFV & $276(34.3 \%)$ & $50(8 \%)$ \\
D4T / 3TC / NVP or EFV & $193(24 \%)$ & $321(51.1 \%)$ \\
TDF / 3TC of FTC / NVP or EFV & $336(41.7 \%)$ & 0.001
\end{tabular}

Categorical variables expressed as $n$ (\%) and continuous variables almost expressed as median (inter-quartile range)

${ }^{\S} \mathrm{p}$-values comparing study participant variables across the three study sites calculated from Kruskal-Wallis test statistic for continuous variables and Pearson $\mathrm{X}^{2}$ test statistic for categorical variables.

All results were assessed at the $5 \%$ level of statistical significance for a 2-sided test. We also compared baseline demographic and laboratory parameters among patients that were sampled at 12 months and those who did not make it to 12 months. Some of the viral load and CD4 samples ( $6 \%$ and $5 \%$ respectively) were missing or were lost at random due to laboratory and / or administrative error. All missing data was assumed missing completely at random (MCAR) and multiple imputations (using sequential regression multivariate imputation (SRMI) method) using STATA did not show any differences in study result interpretation. All analyses were done with STATA version 11 (STATA Corp, College Station, Texas).

\section{Results}

Clinical, demographic, socioeconomic and behavioral descriptions of study population

Figure 1 shows the flow chart and Table 1 summarizes the baseline demographic, clinical, behavioral and socioeconomic characteristics of the study participants. The median age at HAART initiation was 35 years (IQR: $30-$ 41 years) and majority of the patients were females $(\mathrm{n}=400 ; 63.7 \%)$. The baseline median CD4 cell count was 142 cells $/ \mathrm{mm}^{3}$ (IQR: 85-223), baseline median hemoglobin level was $10.9 \mathrm{~g} / \mathrm{dl}$ (IQR: 9.3-12.4) and anemia based on hemoglobin less than $10 \mathrm{~g} / \mathrm{dl}$ was common $(\mathrm{n}=192 ; 35.2 \%)$. Majority of the patients were married $(\mathrm{n}=359 ; 57.2 \%)$. HIV disclosure was high $(\mathrm{n}=595 ; 94.7 \%)$ and most of the patients $(n=402 ; 64 \%)$ lived less than 50 kilometers from their respective treatment sites. More than half of the patients $(n=321 ; 51.1 \%)$ were on a TDFcontaining regimen at baseline with no substitutions within the 12 months. Even though low educational achievement levels with no formal education were seen in 301 (47.9\%) patients, however, socio-economic indicators showed high employment levels $(n=524 ; 83.4 \%)$.
There were differences in patients' characteristics by site on all variables except marital status, HIV disclosure, adherence by self-report, smoking and drug use history. Males differed significantly from females in age at HAART initiation, marital status, TB history, baseline CD4 cell count, baseline hemoglobin count, employment status and smoking and alcohol history. This study was focused on outcomes among those alive at 12 months, and because of the random selection of patients, there were no major differences in the 628 patients selected for the study and the other 1152 who were alive at 12 months and not selected for the study (data not shown). There were differences in the baseline characteristics of age, residential distance from treatment site, baseline CD4 count, baseline anemia status and anti-retroviral drug regimen between the patients who were lost-to-follow-up and those alive and in the study at 12 months (Table 2). The outcomes and associations of patients lost-to-follow-up is in another related paper while this paper focuses on those who were alive at 12 months.

\section{Immuno-virologic parameters at $\mathbf{1 2}$ months on ART}

Of the 591 with completed and validated viral load results, 453 had viral load results $<400$ copies/ml giving a virologic suppression rate of $76.7 \%$ and thus a virologic failure rate of $23.4 \%$. The median baseline CD4 cell count for patients with viral load < 400 copies / $\mathrm{ml}$ was 147 cells $/ \mathrm{mm}^{3}$ (IQR: 87-225) compared to those with viral load > 400 at 122 cells $/ \mathrm{mm}^{3}$ (IQR: 76-196) (p-value 0.04). Of 596 patients with CD4 cell counts (32 samples were not usable due to laboratory mishaps or administrative error) the immunologic failure rate was $22.7 \%$. While $60 \%(n=338)$ had ideal immuno-virologic success $\left(\mathrm{VL}^{+} / \mathrm{CD}^{+}\right)$, immuno-virologic discordance rate was 33\% (Table 2) with $17 \%(n=94)$ of the patients having had virologic failure with immunologic success $\left(\mathrm{VL}^{-} / \mathrm{CD} 4^{+}\right)$and $16 \%(\mathrm{n}=90)$ of the patients 
Table 3 Logistic regression analysis of predictors for virologic failure ( $>400$ copies/ml) among Nigerian adult patients on ART

\section{Characteristics}

\begin{tabular}{|c|c|c|c|c|c|c|}
\hline & $\begin{array}{c}\text { ALL } \\
(n=591)\end{array}$ & $\begin{array}{l}\text { Virologic failure } \\
\qquad(n=138)\end{array}$ & $\begin{array}{l}\text { Unadjusted } \\
\text { OR }(95 \% \mathrm{Cl})\end{array}$ & p-value & $\begin{array}{c}\text { Adjusted } \\
\text { OR }(95 \% \mathrm{CI})\end{array}$ & $p$-value \\
\hline \multicolumn{7}{|l|}{ Gender } \\
\hline Female & 374 & $87(63 \%)$ & Ref & & Ref & 0.33 \\
\hline Male & 217 & $51(37 \%)$ & $1.01(0.68-1.5)$ & 0.95 & $1.40(0.72-2.07)$ & \\
\hline \multicolumn{7}{|l|}{ Age at HAART Initiation (years) } \\
\hline$<30$ & 175 & $42(30.4 \%)$ & $1.51(0.98-2.3)$ & 0.06 & $1.79(1.17-2.67)$ & 0.03 \\
\hline$>30$ & 416 & $96(69.6 \%)$ & Ref & & Ref & \\
\hline \multicolumn{7}{|l|}{ Currently married } \\
\hline Yes & 339 & 79 (43\%) & $0.99(0.68-1.46)$ & 0.98 & & \\
\hline No & 252 & $59(57 \%)$ & Ref & & & \\
\hline \multicolumn{7}{|c|}{ Residential Distance (in kilometers) } \\
\hline$<50$ & 372 & $90(65 \%)$ & Ref & & Ref & \\
\hline 51 to 100 & 80 & $10(7 \%)$ & $0.45(0.22-0.92)$ & 0.03 & $0.44(0.22-0.84)$ & 0.04 \\
\hline$>100$ & 143 & $38(28 \%)$ & $1.17(0.73-1.87)$ & 0.49 & $1.37(0.91-2.35)$ & 0.24 \\
\hline \multicolumn{7}{|l|}{ HIV disclosure } \\
\hline Yes & 559 & $132(96 \%)$ & $0.75(0.30-1.85)$ & 0.53 & & \\
\hline No & 32 & $6(4 \%)$ & Ref & & & \\
\hline \multicolumn{7}{|l|}{ Tuberculosis History } \\
\hline Yes & 84 & $26(19 \%)$ & $1.58(0.95-2.63)$ & 0.08 & $1.20(0.72-2.28)$ & 0.46 \\
\hline No & 507 & $112(81 \%)$ & Ref & & Ref & \\
\hline \multicolumn{7}{|c|}{ Baseline CD4 cell count $(n=613)$} \\
\hline$<50$ & 85 & $24(17 \%)$ & Ref & & Ref & \\
\hline 50 and $<200$ & 317 & 79 (57\%) & $0.84(0.49-1.44)$ & 0.54 & $0.82(0.47-1.46)$ & 0.53 \\
\hline 200 and $<350$ & 143 & $26(19 \%)$ & $0.56(0.30-1.07)$ & 0.08 & $0.54(0.22-0.93)$ & 0.08 \\
\hline 350 and $<500$ & 22 & $5(4 \%)$ & $0.75(0.25-2.25)$ & 0.61 & $0.48(0.17-2.53)$ & 0.24 \\
\hline$>=500$ & 24 & $4(3 \%)$ & $0.51(0.16-1.64)$ & 0.26 & $0.58(0.19-2.6)$ & 0.38 \\
\hline \multicolumn{7}{|c|}{ Baseline anemia Hemoglobin $<10 \mathrm{~g} / \mathrm{dl})(\mathrm{n}=591)$} \\
\hline Yes & 200 & $58(42 \%)$ & $1.59(1.07-2.35)$ & 0.02 & $1.71(1.22-2.61)$ & 0.03 \\
\hline No & 391 & $84(58 \%)$ & Ref & & Ref & \\
\hline \multicolumn{7}{|c|}{ Antiretroviral drug regimen at baseline } \\
\hline ZDV / 3TC / NVP or EFV & 247 & $56(40.6 \%)$ & Ref & & Ref & \\
\hline D4T / 3TC / NVP or EFV & 48 & $14(10.1 \%)$ & $1.32(0.70-2.80)$ & 0.34 & $1.35(0.64-2.95)$ & 0.45 \\
\hline TDF / 3TC of FTC / NVP or EFV & 296 & $68(50.3 \%)$ & $0.94(0.68-1.52)$ & 0.93 & $0.90(0.65-1.66)$ & 0.79 \\
\hline \multicolumn{7}{|l|}{ Baseline Functionality } \\
\hline Working (70-100\%) & 460 & $96(71.1 \%)$ & Ref & & Ref & \\
\hline Ambulatory (50-70\%) & 106 & $34(25.2 \%)$ & $0.32(0.09-1.06)$ & 0.062 & $0.34(0.12-1.18)$ & 0.09 \\
\hline Bedridden $(<50 \%)$ & 11 & $5(3.7 \%)$ & $0.57(0.16-1.99)$ & 0.375 & $0.60(0.14-1.87)$ & 0.39 \\
\hline \multicolumn{7}{|c|}{ Drug adherence by pharmacy refill record } \\
\hline$>=95 \%$ & 543 & $114(80 \%)$ & Ref & & Ref & \\
\hline$<95 \%$ & 48 & $24(20 \%)$ & $3.76(2.06-6.87)$ & 0.001 & $3.82(2.17-5.97)$ & 0.001 \\
\hline
\end{tabular}


Table 3 Logistic regression analysis of predictors for virologic failure ( $>400$ copies $/ \mathrm{ml}$ ) among Nigerian adult patients on ART (Continued)

\begin{tabular}{|c|c|c|c|c|c|c|}
\hline \multicolumn{7}{|l|}{ Employment status } \\
\hline Employed & 496 & $111(80 \%)$ & Ref & & Ref & \\
\hline Unemployed & 90 & $26(19 \%)$ & $1.41(0.85-2.33)$ & 0.18 & 1. $37(0.88-2.10)$ & 0.26 \\
\hline Retired & 1 & $0(0 \%)$ & Omitted & Omitted & Omitted & \\
\hline Student & 4 & $1(1 \%)$ & $1.16(0.12-11.2)$ & 0.90 & $1.18(0.15-10.6)$ & 0.94 \\
\hline \multicolumn{7}{|l|}{ Highest educational achievement } \\
\hline No formal education & 283 & $80(58 \%)$ & Ref & & Ref & \\
\hline Primary education & 131 & $26(19 \%)$ & $0.63(0.38-1.04)$ & 0.07 & $0.66(0.39-1.07)$ & 0.06 \\
\hline Secondary education & 30 & $7(5 \%)$ & $0.77(0.32-1.87)$ & 0.57 & $0.74(0.31-1.79)$ & 0.61 \\
\hline Post-secondary / Tertiary / Advanced education (M.Sc, PhD) & 147 & $25(18 \%)$ & $0.53(0.32-0.88)$ & 0.01 & $0.60(0.30-0.86)$ & 0.02 \\
\hline \multicolumn{7}{|l|}{ Socio-economic class } \\
\hline Class 1 & 23 & $6(4 \%)$ & Ref & & & \\
\hline Class 2 & 93 & $18(13 \%)$ & $0.68(0.23-1.97)$ & 0.48 & & \\
\hline Class 3 & 260 & $55(40 \%)$ & $0.76(0.29-2.02)$ & 0.58 & & \\
\hline Class 4 & 195 & $55(40 \%)$ & $1.11(0.42-2.97)$ & 0.83 & & \\
\hline Class 5 & 20 & $4(3 \%)$ & $0.71(0.17-2.98)$ & 0.64 & & \\
\hline \multicolumn{7}{|l|}{ Current smoker } \\
\hline Yes & 10 & $3(2 \%)$ & $1.42(0.36-5.55)$ & 0.62 & & \\
\hline No & 581 & 135 (98\%) & Ref & & & \\
\hline \multicolumn{7}{|l|}{ Current drug user } \\
\hline Yes & 1 & $0(0 \%)$ & Omitted & Omitted & & \\
\hline No & 590 & $138(100 \%)$ & Ref & & & \\
\hline \multicolumn{7}{|l|}{ Current alcohol user } \\
\hline Yes & 47 & $14(10 \%)$ & $1.44(0.75-2.77)$ & 0.28 & & \\
\hline No & 544 & $124(90 \%)$ & Ref & & & \\
\hline \multicolumn{7}{|l|}{ Current herbal drug user } \\
\hline Yes & 17 & $6(4 \%)$ & $1.83(0.66-5.03)$ & 0.24 & & \\
\hline No & 574 & $132(96 \%)$ & Ref & & & \\
\hline
\end{tabular}

In the adjusted analysis, site was adjusted for in addition to the variables whose OR are included in the table.

having had immunologic failure with virologic success $\left(\mathrm{VL}^{+} / \mathrm{CD} 4^{-}\right)$.

\section{Predictors of virologic and immunologic outcomes at 12 months on ART}

In the univariate logistic model (Table 3), a decreased odds of virologic failure was significantly associated with residential distance 51-100 kilometers (OR 0.45; 95\% CI: 0.22-0.92) compared to residential distance less than 50 kilometers, and post-secondary/tertiary educational achievement (OR 0.53; 95\% CI: 0.32-0.88) compared with no formal education. An increased odds of virologic failure was significantly associated with anemia with hemoglobin <10 g/dl (OR 1.59; 95\% CI: 1.07-2.35) and with poor drug adherence of $<95 \%$ both by pharmacy refill record (OR 3.76; 95\% CI: 2.06-6.87) and selfreported adherence (OR 1.79; 95\% CI: 1.07-2.99). After adjusting for site of study and other potential confounders, a decreased odds of virologic failure was still significantly associated with residential distance and postsecondary / tertiary educational achievement (OR 0.60; 95\% CI: 0.30-0.86). Also, an increased odds of virologic failure remained significantly associated with age less than 30 years (OR 1.79; 95\% CI: 1.17-2.67), anemia with hemoglobin less than $10 \mathrm{~g} / \mathrm{dl}$ (OR 1.71; 95\% CI 1.22$2.62)$ and adherence by pharmacy refill record $<95 \%$ (OR 3.82; 95\% CI: 2.17-5.97).

A decreased odds of immunologic failure was not significantly associated with any predictor in the univariate or multivariate regression models (Table 4). However, an increased odds of immunologic failure was significantly associated with age less than 30 years (OR 1.55; 95\% CI: 1.01-2.37) in the univariate model, and with male gender (OR 1.46; 95\% CI: 1.04-2.45), age less than 
Table 4 Logistic regression analysis of predictors for immunologic failure (Fall of CD4 count to or below baseline or CD4 cell count change $<50$ cells $/ \mathrm{mm}^{3}$ at one year) among Nigerian adult patients on ART

Characteristics

\begin{tabular}{|c|c|c|c|c|c|c|}
\hline & $\begin{array}{c}\text { ALL } \\
(n=596)\end{array}$ & $\begin{array}{l}\text { Immunologic failure } \\
\qquad(\mathrm{n}=135)\end{array}$ & $\begin{array}{l}\text { Unadjusted } \\
\text { OR }(95 \% \mathrm{Cl})\end{array}$ & p-value & $\begin{array}{c}\text { Adjusted } \\
\text { OR }(95 \% \mathrm{Cl})\end{array}$ & p-value \\
\hline \multicolumn{7}{|l|}{ Gender } \\
\hline Female & 377 & $84(62 \%)$ & Ref & & Ref & \\
\hline Male & 219 & $51(38 \%)$ & $1.06(0.71-1.57)$ & 0.78 & $1.46(1.04-2.45)$ & 0.04 \\
\hline \multicolumn{7}{|l|}{ Age at HAART Initiation (years) } \\
\hline$<30$ & 178 & $42(31 \%)$ & $1.55(1.01-2.37)$ & 0.04 & $1.50(1.11-2.39)$ & 0.03 \\
\hline$>30$ & 357 & $93(69 \%)$ & Ref & & Ref & \\
\hline \multicolumn{7}{|l|}{ Currently married } \\
\hline Yes & 336 & $76(56 \%)$ & $0.99(0.68-1.47)$ & 0.98 & & \\
\hline No & 260 & $59(44 \%)$ & Ref & & & \\
\hline \multicolumn{7}{|l|}{ Residential Distance (in kilometers) } \\
\hline$<50$ & 376 & $92(68 \%)$ & Ref & & Ref & \\
\hline 51 to100 & 78 & 19 (14\%) & $0.99(0.56-1.75)$ & 0.98 & $1.19(0.64-2.33)$ & 0.79 \\
\hline$>100$ & 142 & $24(18 \%)$ & $0.63(0.38-1.03)$ & 0.07 & $0.68(0.40-1.21)$ & 0.32 \\
\hline \multicolumn{7}{|l|}{ HIV disclosure } \\
\hline Yes & 564 & $129(22.9 \%)$ & $0.78(0.31-1.93)$ & 0.59 & & \\
\hline No & 32 & $6(18.8 \%)$ & Ref & & & \\
\hline \multicolumn{7}{|l|}{ Tuberculosis History } \\
\hline Yes & 85 & $14(29.6 \%)$ & $0.64(0.35-1.17)$ & 0.14 & $0.66(0.40-1.36)$ & 0.27 \\
\hline No & 511 & $121(70.4 \%)$ & Ref & & Ref & \\
\hline \multicolumn{7}{|l|}{ Baseline anemia (Hemoglobin $<10 \mathrm{~g} / \mathrm{dl})(\mathrm{n}=546)$} \\
\hline Yes & 186 & $40(20.4 \%)$ & $1.26(0.83-1.92)$ & 0.27 & $1.05(0.65-1.61)$ & 0.75 \\
\hline No & 410 & $95(23.7 \%)$ & Ref & & Ref & \\
\hline \multicolumn{7}{|l|}{ Antiretroviral drug regimen at baseline } \\
\hline ZDV / 3TC / NVP or EFV & 242 & $58(43 \%)$ & Ref & & & \\
\hline D4T / 3TC / NVP or EFV & 47 & $13(9.6 \%)$ & $1.21(0.59-2.45)$ & 0.59 & $1.61(0.69-3.53)$ & 0.29 \\
\hline TDT / 3TC or FTC / NVP or EFV & 307 & $64(47.4 \%)$ & $0.84(0.56-1.25)$ & 0.38 & $1.14(0.77-1.53)$ & 0.83 \\
\hline \multicolumn{7}{|l|}{ Drug adherence by pharmacy refill record } \\
\hline$>=95 \%$ & 549 & $122(90.4 \%)$ & Ref & & Ref & \\
\hline$<95 \%$ & 47 & $13(9.6 \%)$ & $1.34(0.68-2.61)$ & 0.39 & $1.42(0.71-2.86)$ & 0.28 \\
\hline \multicolumn{7}{|l|}{ Employment status } \\
\hline Employed & 496 & $110(81.5 \%)$ & Ref & & & \\
\hline Unemployed & 95 & $25(18.5 \%)$ & $1.25(0.76-2.07)$ & 0.38 & & \\
\hline Retired & 1 & $0(0 \%)$ & Omitted & Omitted & & \\
\hline Student & 4 & $0(0 \%)$ & Omitted & Omitted & & \\
\hline \multicolumn{7}{|l|}{ Highest educational achievement } \\
\hline No formal education & 288 & $64(47.4 \%)$ & Ref & & & \\
\hline Primary education & 134 & $28(20.7 \%)$ & $0.92(0.56-1.53)$ & 0.76 & & \\
\hline Secondary education & 32 & $10(7.4 \%)$ & $1.59(0.72-3.53)$ & 0.25 & & \\
\hline Post-secondary / Tertiary / Advanced education (M.Sc., Ph.D.) & 142 & $33(24.4 \%)$ & $1.09(0.67-1.76)$ & 0.73 & & \\
\hline
\end{tabular}


Table 4 Logistic regression analysis of predictors for immunologic failure (Fall of CD4 count to or below baseline or CD4 cell count change $<\mathbf{5 0}$ cells $/ \mathrm{mm}^{3}$ at one year) among Nigerian adult patients on ART (Continued)

\begin{tabular}{|c|c|c|c|c|}
\hline \multicolumn{5}{|c|}{ Socio-economic class } \\
\hline Class 1 & 22 & $4(3 \%)$ & Ref & \\
\hline Class 2 & 91 & 17 (12.6\%) & $1.03(0.31-3.45)$ & 0.96 \\
\hline Class 3 & 262 & $68(50.4 \%)$ & $1.58(0.52-4.82)$ & 0.42 \\
\hline Class 4 & 199 & $42(31 \%)$ & $1.20(0.39-3.75)$ & 0.75 \\
\hline Class 5 & 22 & $4(3 \%)$ & $1.00(0.22-4.63)$ & 1.00 \\
\hline \multicolumn{5}{|c|}{ Current smoker } \\
\hline Yes & 11 & $4(97 \%)$ & $1.98(0.57-6.87)$ & 0.28 \\
\hline No & 585 & $131(3 \%)$ & Ref & \\
\hline \multicolumn{5}{|c|}{ Current drug user } \\
\hline Yes & 0 & $0(0 \%)$ & Omitted & Omitted \\
\hline No & 596 & 135 (100\%) & Ref & \\
\hline \multicolumn{5}{|c|}{ Current alcohol user } \\
\hline Yes & 50 & $8(6 \%)$ & $0.63(0.29-1.37)$ & 0.24 \\
\hline No & 546 & $127(94 \%)$ & Ref & \\
\hline \multicolumn{5}{|c|}{ Current herbal drug user } \\
\hline Yes & 17 & $6(4 \%)$ & $1.90(0.69-5.24)$ & 0.21 \\
\hline No & 579 & $129(96 \%)$ & Ref & \\
\hline
\end{tabular}

30 years (OR 1.50; 95\% CI: 1.11-2.39) in the multivariate regression model.

\section{Predictors of Immuno-virologic discordance at 12 months} on ART

In the multivariate regression model, an increased odds of $\mathrm{VL}^{-} / \mathrm{CD}^{+}$compared to $\mathrm{VL}^{+} / \mathrm{CD}^{+}$was significantly associated with poor adherence as monitored by pharmacy refill records (OR 3.90; 95\% CI: 1.92-8.24) and anemia (Hemoglobin < $10 \mathrm{~g} / \mathrm{dl}$ ) (OR 1.80; 95\% CI: 1.132.85) while decreased odds was associated with postsecondary educational achievement (OR 0.40; 95\% CI: 0.22-0.68) (Table 5). Compared with $\mathrm{VL}^{+} / \mathrm{CD}^{+}$, odds of $\mathrm{VL}^{+} / \mathrm{CD} 4-$ was significantly associated with male gender (OR 1.88; 95 CI: 1.05-3.11) and higher baseline CD4 > 200 (9.90: 95\% CI: 2.79-35.10) (Table 6).

\section{Discussion}

To our knowledge, this is one of the first longitudinal HIV immuno-virologic outcome and immuno-virologic discordance study done in large multi-center non-research public health facilities in Nigeria. Although favorable immuno-virologic outcomes could be achieved in this large ART program in which over half of the patients are on TDF-containing first-line, immuno-virologic discordance was observed in a third of the patients. Our findings provide important insights into specific predictors of immuno-virologic outcomes that are important for optimizing treatment strategies.
The patients were predominantly female reflecting the long standing feminization of the HIV epidemic in Nigeria [18], better health seeking behavior of women and possibly the linkage of treatment sites with the antenatal clinics and the prevention-of-mother-to-child HIV programs. Our study demonstrated that patients with higher baseline CD4 cell counts were statistically significantly more likely to have viral suppression at 12 months; a result in agreement with numerous other studies [19,20]. This well-known trend of late presentation and poorer male outcomes because of poor health seeking behavior of men [21] deserves renewed focus as male involvement in health program could improve decision-making not only for the men themselves but also for the women and children who live in male dominated societies. Men may need to be reached by new strategies for HIV voluntary counseling and testing focused on work and leisure sites frequently visited by men, flexible clinic hours for working men in addition to more aggressive mobilization campaigns targeted to men.

While many others had published on virologic outcomes results in Nigeria showing 62\%-70\% virologic suppression rates, they are mostly derived from a research setting [22-24]. The virologic suppression rate of $77 \%$ seen in this analysis is one of the first and the best seen in a large HIV treatment program from Nigeria and is consistent with a large review of 89 studies of antiretroviral programs in sub-Saharan Africa which showed a pooled virologic suppression rate of $76 \%$ at 12 months [25]. The robust 
Table 5 Logistic regression analysis of predictors of virologic discordance (VL > 400 copies and CD4 change >=50 cell) compared to immuno-virologic success (VL $<400$ copies and CD4 change $>=50$ cells) at 12 month post-HAART among adult patients on ART in Nigeria

\section{Characteristics}

\begin{tabular}{|c|c|c|c|c|c|c|}
\hline & $\begin{array}{l}\text { Immuno-virologic success (VL } \\
<400 \text { copies and CD4 change } \\
>=50 \text { cells) }\end{array}$ & $\begin{array}{c}\text { Virologic discordance }(\mathrm{VL}>400 \\
\text { copies and CD4 change }>=50 \\
\text { cells) }\end{array}$ & Unadjusted & p-value & Adjusted & $\begin{array}{c}\mathrm{p}- \\
\text { value }\end{array}$ \\
\hline & $(n=338)$ & $(n=94)$ & OR $(95 \% \mathrm{Cl})$ & & OR $(95 \% \mathrm{Cl})$ & \\
\hline \multicolumn{7}{|l|}{ Gender } \\
\hline Female & $214(63 \%)$ & $58(62 \%)$ & Ref & & Ref & \\
\hline Male & $124(37 \%)$ & $36(38 \%)$ & $1.07(0.67-1.72)$ & 0.78 & $1.25(0.72-2.01)$ & 0.54 \\
\hline \multicolumn{7}{|c|}{ Age at HAART Initiation (years) } \\
\hline$<30$ & $269(80 \%)$ & $66(70 \%)$ & $1.65(0.99-2.77)$ & 0.06 & $1.58(0.88-3.01)$ & 0.08 \\
\hline$>30$ & $69(20 \%)$ & $28(30 \%)$ & Ref & & Ref & \\
\hline \multicolumn{7}{|c|}{ Currently married } \\
\hline Yes & $188(56 \%)$ & $57(61 \%)$ & $1.23(0.77-1.96)$ & 0.39 & & \\
\hline No & $150(44 \%)$ & $37(39 \%)$ & Ref & & & \\
\hline \multicolumn{7}{|l|}{ HIV disclosure } \\
\hline Yes & 317 (93.8\%) & $89(95 \%)$ & $1.18(0.43-3.22)$ & 0.75 & & \\
\hline No & $21(6.2 \%)$ & $5(5 \%)$ & Ref & & & \\
\hline \multicolumn{7}{|c|}{ Tuberculosis History } \\
\hline Yes & $49(14.5 \%)$ & $17(18.1 \%)$ & $1.30(0.71-2.39)$ & 0.39 & $0.92(0.47-1.86)$ & 0.92 \\
\hline No & $289(85.5 \%)$ & 77 (81.9\%) & Ref & & Ref & \\
\hline \multicolumn{7}{|c|}{ Baseline CD4 cell count $(n=613)$} \\
\hline$<50$ & $57(16.9 \%)$ & $19(20.2 \%)$ & Ref & & Ref & \\
\hline 50 and $<200$ & $196(58 \%)$ & $59(62.8 \%)$ & $0.90(0.50-1.64)$ & 0.74 & $0.90(0.56-1.61)$ & 0.81 \\
\hline 200 and $<350$ & $72(21.3 \%)$ & $13(13.8 \%)$ & $0.54(0.25-1.19)$ & 0.13 & $0.59(0.20-1.38)$ & 0.22 \\
\hline 350 and $<500$ & $9(2.7 \%)$ & $3(3.2 \%)$ & $1.00(0.25-4.08)$ & 1.0 & $0.58(0.16-3.22)$ & 0.65 \\
\hline$>=500$ & $4(1.1 \%)$ & $0(0 \%)$ & Omitted & & & \\
\hline
\end{tabular}

Baseline anemia (Hemoglobin $<10 \mathrm{~g} / \mathrm{dl})(\mathrm{n}=546)$

Yes 103 (30.5\%)

$40(42.5 \%)$

No

$235(69.5 \%)$

Antiretroviral drug regimen at baseline

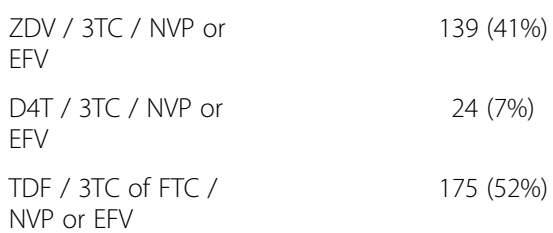

Drug adherence by pharmacy refill record

$$
\begin{array}{lc}
>=95 \% & 322(95 \%) \\
<95 \% & 16(5 \%)
\end{array}
$$

Employment status

$\begin{array}{lc}\text { Employed } & 288(85.2 \%) \\ \text { Unemployed } & 46(13.6 \%) \\ \text { Retired } & 1(0.3 \%) \\ \text { Student } & 3(0.9 \%)\end{array}$

$54(57.5 \%)$

$37(39 \%)$

$9(10 \%)$

$48(51 \%)$

79 (84\%)

$15(16 \%)$

75 (79.8\%)

$18(19.1 \%)$

$0(0 \%)$

$1(1.1 \%)$
$1.69(1.05-2.70) \quad 0.03 \quad 1.80(1.13-2.85) \quad 0.04$ Ref Ref

Ref

$1.41(0.60-3.29) \quad 0.43 \quad 1.21(0.42-3.95) \quad 0.59$

$1.03(0.64-1.67) \quad 0.90 \quad 0.89(0.46-1.43) \quad 0.86$

Ref Ref

$3.82(1.81-8.06) \quad 0.001 \quad 3.90(1.92-8.24) \quad 0.001$

Ref Ref

$1.50(0.82-2.74) \quad 0.18 \quad 1.44(0.77-2.56) \quad 0.31$

Omitted Omitted Omitted

$1.28(0.13-12.5) \quad 0.83 \quad 1.33(0.15-11.7) \quad 0.87$ 
Table 5 Logistic regression analysis of predictors of virologic discordance (VL > 400 copies and CD4 change >=50 cell) compared to immuno-virologic success (VL $<400$ copies and CD4 change $>=50$ cells) at 12 month post-HAART among adult patients on ART in Nigeria (Continued)

\begin{tabular}{|c|c|c|c|c|c|c|}
\hline \multicolumn{7}{|c|}{ Highest educational achievement } \\
\hline No formal education & $152(45 \%)$ & $58(61.7 \%)$ & Ref & & Ref & \\
\hline Primary education & $84(24.9 \%)$ & $18(19.2 \%)$ & $0.56(0.31-1.02)$ & 0.06 & $0.56(0.29-1.01)$ & 0.06 \\
\hline Secondary education & $14(4.1 \%)$ & $5(5.3 \%)$ & $0.94(0.32-2.72)$ & 0.90 & $0.92(0.27-2.49)$ & 0.72 \\
\hline $\begin{array}{l}\text { Post-secondary / } \\
\text { Tertiary / Advanced } \\
\text { education }\end{array}$ & $88(26 \%)$ & $13(13.8 \%)$ & $0.40(0.21-0.77)$ & 0.006 & $0.40(0.22-0.68)$ & 0.004 \\
\hline \multicolumn{7}{|l|}{ Socio-economic class } \\
\hline Class 1 & $14(4.1 \%)$ & $4(4.3 \%)$ & Ref & & & \\
\hline Class 2 & $54(16 \%)$ & $14(14.9 \%)$ & $0.91(0.26-3.19)$ & 0.88 & & \\
\hline Class 3 & $147(43.5 \%)$ & $33(35.1 \%)$ & $0.79(0.24-2.54)$ & 0.69 & & \\
\hline Class 4 & $110(32.5 \%)$ & $41(43.6 \%)$ & $\begin{array}{c}1.30 \\
(0.41-.4 .19)\end{array}$ & 0.66 & & \\
\hline Class 5 & $13(3.9 \%)$ & $2(2.1 \%)$ & $0.54(0.08-3.45)$ & 0.51 & & \\
\hline \multicolumn{7}{|l|}{ Current smoker } \\
\hline Yes & $5(1.5 \%)$ & 1 (98.9\%) & $0.72(0.08-6.21)$ & 0.76 & & \\
\hline No & $333(98.5 \%)$ & $93(1.1 \%)$ & Ref & & & \\
\hline \multicolumn{7}{|l|}{ Current alcohol user } \\
\hline Yes & $28(8.3 \%)$ & $8(8.5 \%)$ & $1.03(0.45-2.34)$ & 0.94 & & \\
\hline No & 310 (91.7\%) & $86(91.5 \%)$ & Ref & & & \\
\hline \multicolumn{7}{|c|}{ Current herbal drug user } \\
\hline Yes & $7(2.1 \%)$ & $3(3.2 \%)$ & $1.56(0.39-6.15)$ & 0.53 & & \\
\hline No & $331(97.9 \%)$ & 91 (96.8\%) & Ref & & & \\
\hline
\end{tabular}

immunologic response of $>50$ cells $/ \mathrm{mm}^{3}$ was seen in $77.4 \%$ of patients at 12 months with a median CD4 cell count increase of 139 cells / $\mathrm{mm}^{3}$ which is consistent with results obtained in other programs in similar settings [26,27]. Since more than half of the entire patient cohort were on a Tenofovir-containing regimen which is known for its superiority, convenient dosing, low toxicity and high potency [28-30], we were expecting a lower virologic failure rate than $23 \%$. However, there were no statistically significant differences in virologic suppression by baseline drug regimen among this study cohort. These encouraging results confirm that favorable virologic and immunologic outcomes can be obtained from government-run busy large public health HIV treatment programs through technical assistance of PEPFAR implementing partners.

The finding of a strong association of virologic failure with anemia is noteworthy. Previous studies have associated anemia with poorer survival [31-33] and our findings suggest a $71 \%$ increased odds of virologic failure with anemia at baseline in addition to a $80 \%$ increased odds of virologic discordance. Apart from anemia caused by HIV itself and malnutrition, malaria and chronic helminthiasis are two most common causes of anemia in adults that respond to potent chemo-therapeutic interventions. Thus identifying and managing adults with anemia at baseline when HAART is being initiated as well as providing anti-helminthics can improve anemia and possibly retention and virologic outcome. A systematic review of 43 studies on the impact of hookworm infestation and anemia showed that treating nonpregnant adults with a combination of albendazole and praziquantel will increase hemoglobin level by a mean of $2.87 \mathrm{~g} / \mathrm{dl}$ [34]. Based on the strong association of virologic failure and $\mathrm{VL}^{-} / \mathrm{CD}^{+}$discordance and anemia obtained in our study, chronic infections with anemia may be interfering with immuno-virologic recovery on HAART. We therefore recommend that a comprehensive treatment preparation and nutritional counseling program include anemia screening and management incorporating malaria and chronic helminthiasis treatment and provision of hematinics as a priority around the time of HAART initiation.

Younger age $<30$ years was significantly associated with $79 \%$ increased odds of virologic failure and 50\% increased odds of immunologic failure. A majority of studies including one previous evaluation of the $A C T I O N$ program in Nigeria demonstrated an association between adherence 
Table 6 Logistic regression analysis of predictors of immunologic discordance (VL $<400$ copies and CD4 change $<50$ cells) compared to immuno-virologic success (VL $<400$ copies and CD4 change $>=50$ cells) at 12 month post-HAART among adult patients on ART in Nigeria

\begin{tabular}{|c|c|c|c|c|c|c|}
\hline \multicolumn{7}{|l|}{ Characteristics } \\
\hline & $\begin{array}{c}\text { Immuno-virologic success (VL } \\
<400 \text { copies and CD4 change } \\
>=50 \text { cells) }\end{array}$ & $\begin{array}{l}\text { Immunologic discordance (VL } \\
<400 \text { copies and CD4 change } \\
<50 \text { cells) }\end{array}$ & Unadjusted & $\begin{array}{c}\text { p- } \\
\text { value }\end{array}$ & Adjusted & $\begin{array}{l}\mathrm{p}- \\
\text { value }\end{array}$ \\
\hline & $(n=338)$ & $(n=90)$ & OR $(95 \% \mathrm{Cl})$ & & OR $(95 \% \mathrm{Cl})$ & \\
\hline \multicolumn{7}{|l|}{ Gender } \\
\hline Female & $214(63 \%)$ & $55(61.1 \%)$ & Ref & & Ref & \\
\hline Male & $124(37 \%)$ & $35(38.9 \%)$ & $1.09(0.68-1.77)$ & 0.90 & $1.88(1.05-3.11)$ & 0.04 \\
\hline \multicolumn{7}{|c|}{ Age at HAART Initiation (years) } \\
\hline$<30$ & $269(80 \%)$ & $27(30 \%)$ & $1.67(0.99-2.82)$ & 0.05 & $1.76(0.91-3.20)$ & 0.08 \\
\hline$>30$ & $69(20 \%)$ & $63(70 \%)$ & Ref & & Ref & \\
\hline \multicolumn{7}{|l|}{ Currently married } \\
\hline Yes & $188(56 \%)$ & $54(60 \%)$ & $1.19(0.75-1.92)$ & 0.46 & & \\
\hline No & $150(44 \%)$ & $36(40 \%)$ & Ref & & & \\
\hline \multicolumn{7}{|l|}{ HIV disclosure } \\
\hline Yes & $317(93.8 \%)$ & $86(95.6 \%)$ & $1.42(0.48-4.26)$ & 0.53 & & \\
\hline No & $21(6.2 \%)$ & $4(4.4 \%)$ & Ref & & & \\
\hline \multicolumn{7}{|c|}{ Tuberculosis History } \\
\hline Yes & $49(14.5 \%)$ & $5(5.6 \%)$ & $0.35(0.13-0.90)$ & 0.03 & $0.43(0.21-1.09)$ & 0.08 \\
\hline No & $289(85.5 \%)$ & $85(94.4 \%)$ & Ref & & Ref & \\
\hline \multicolumn{7}{|c|}{ Baseline CD4 cell count $(n=613)$} \\
\hline$<50$ & $57(16.9 \%)$ & $3(3.3 \%)$ & Ref & & Ref & \\
\hline 50 and $<200$ & $196(58 \%)$ & 35 (38.9\%) & $3.39(1.01-11.44)$ & 0.049 & $3.17(0.93-10.86)$ & 0.07 \\
\hline 200 and $<350$ & $72(21.3 \%)$ & $42(46.7 \%)$ & $11.08(3.27-37.61)$ & 0.001 & $9.90(2.79-35.10)$ & $>0.001$ \\
\hline 350 and $<500$ & $9(2.7 \%)$ & $6(6.7 \%)$ & $12.67(2.68-59.92$ & 0.001 & $13.5(2.59-70.13)$ & 0.002 \\
\hline$>=500$ & $4(1.1 \%)$ & $4(4.4 \%)$ & $18.99(3.12-115.86$ & 0.001 & $19.1(2.91-125.59)$ & 0.002 \\
\hline \multicolumn{7}{|c|}{ Baseline anemia (Hemoglobin $<10 \mathrm{~g} / \mathrm{dl})(\mathrm{n}=546)$} \\
\hline Yes & $103(30.5 \%)$ & $24(26.7 \%)$ & $1.21(0.72-2.03)$ & 0.48 & $1.04(0.55-1.88)$ & 0.94 \\
\hline No & $235(69.5 \%)$ & $66(73.3 \%)$ & Ref & & Ref & \\
\hline \multicolumn{7}{|c|}{ Antiretroviral drug regimen at baseline } \\
\hline $\begin{array}{l}\text { ZDV / 3TC / NVP or } \\
\text { EFV }\end{array}$ & $139(41 \%)$ & $39(43.3 \%)$ & Ref & & Ref & \\
\hline $\begin{array}{l}\text { D4T / 3TC / NVP or } \\
\text { EFV }\end{array}$ & $24(7 \%)$ & $8(8.9 \%)$ & $1.18(0.49-2.85)$ & 0.70 & $1.74(0.64-4.76)$ & 0.25 \\
\hline $\begin{array}{l}\text { TDF / 3TC of FTC / } \\
\text { NVP or EFV }\end{array}$ & $175(52 \%)$ & $43(47.8 \%)$ & $0.88(0.54-1.43)$ & 0.59 & $1.29(0.72-2.22)$ & 0.43 \\
\hline \multicolumn{7}{|c|}{ Drug adherence by pharmacy refill record } \\
\hline$>=95 \%$ & $322(95 \%)$ & $85(94.4 \%)$ & Ref & & Ref & \\
\hline$<95 \%$ & $16(5 \%)$ & $5(5.6 \%)$ & $1.18(0.43-3.22)$ & 0.75 & $1.20(0.41-2.91)$ & 0.64 \\
\hline \multicolumn{7}{|l|}{ Employment status } \\
\hline Employed & $288(85.2 \%)$ & $74(82.2 \%)$ & Ref & & & \\
\hline Unemployed & $46(13.6 \%)$ & $16(17.8 \%)$ & $1.35(0.73-2.53)$ & 0.34 & & \\
\hline Retired & $1(0.3 \%)$ & $0(0 \%)$ & Omitted & & & \\
\hline Student & $3(0.9 \%)$ & $0(0 \%)$ & Omitted & & & \\
\hline
\end{tabular}


Table 6 Logistic regression analysis of predictors of immunologic discordance (VL $<400$ copies and CD4 change $<50$ cells) compared to immuno-virologic success (VL $<400$ copies and CD4 change $>=50$ cells) at 12 month post-HAART among adult patients on ART in Nigeria (Continued)

\begin{tabular}{|c|c|c|c|c|c|c|}
\hline \multicolumn{7}{|c|}{ Highest educational achievement } \\
\hline No formal education & $152(45 \%)$ & $41(45.6 \%)$ & Ref & & \multicolumn{2}{|l|}{ Ref } \\
\hline Primary education & $84(24.9 \%)$ & $20(22.2 \%)$ & $0.88(0.49-1.60)$ & 0.68 & & \\
\hline Secondary education & $14(4.1 \%)$ & $7(7.8 \%)$ & $1.85(0.70-4.89)$ & 0.21 & & \\
\hline $\begin{array}{l}\text { Post-secondary / } \\
\text { Tertiary / Advanced } \\
\text { education }\end{array}$ & $88(26 \%)$ & $22(24.4 \%)$ & $0.96(0.54-1.72)$ & 0.89 & & \\
\hline \multicolumn{7}{|l|}{ Socio-economic class } \\
\hline Class 1 & $14(4.1 \%)$ & $2(2.2 \%)$ & Ref & & & \\
\hline Class 2 & $54(16 \%)$ & $13(14.5 \%)$ & $1.69(0.34-8.35)$ & 0.52 & & \\
\hline Class 3 & 147 (43.5\%) & 48 (53.3\%) & $2.29(0.50-10.40)$ & 0.29 & & \\
\hline Class 4 & $110(32.5 \%)$ & $25(27.8 \%)$ & $1.59(0.34-7.45)$ & 0.56 & & \\
\hline Class 5 & $13(3.9 \%)$ & $2(2.2 \%)$ & $1.08(0.13-8.79)$ & 0.95 & & \\
\hline \multicolumn{7}{|l|}{ Current smoker } \\
\hline Yes & $5(1.5 \%)$ & $2(2.2 \%)$ & $1.51(0.29-7.93)$ & 0.62 & & \\
\hline No & $333(98.5 \%)$ & $88(97.8 \%)$ & Ref & & & \\
\hline \multicolumn{7}{|l|}{ Current alcohol user } \\
\hline Yes & $28(8.3 \%)$ & $3(3.3 \%)$ & $0.38(0.11-1.29)$ & 0.12 & $0.28(0.09-1.27)$ & 0.09 \\
\hline No & $310(91.7 \%)$ & $87(96.7 \%)$ & Ref & & Ref & \\
\hline \multicolumn{7}{|c|}{ Current herbal drug user } \\
\hline Yes & $7(2.1 \%)$ & $3(3.3 \%)$ & $1.63(0.41-6.44)$ & 0.49 & & \\
\hline No & $331(97.9 \%)$ & 87 (96.7\%) & Ref & & & \\
\hline
\end{tabular}

and improved outcomes increasing with age [35-37]. Young people are more likely to be single, engage in high risk behaviors, lack social capital, financial ability and maturity [38-40] and thus should be prioritized in treatment preparation and adherence support programs.

Most studies including an extensive review of barriers to accessing HIV treatment and negative treatment outcomes suggest that longer distances from treatment sites are associated with poorer outcomes [37,41]. In our study, it appears that compared to those living less than 50 miles of the treatment site, those who lived 50100 kilometers away had a 56\% significantly decreased odds of virologic failure while those who lived the farthest (> 100 kilometers) had a $37 \%$ increased odds of virologic failure that was not significant. Since most Nigerians live close to the more than 300 HIV treatment sites in the country, it appears that adherent patients who travel $>50$ kilometers to treatment centers make the personal choice to travel that long distance and are probably more motivated than patients who live close to the clinic. However, the farther the patients reside (> 100 kilometers) the greater the difficulty of handling the logistic and financial challenge of a far residential distance. A sub-analysis of our data confirmed that drug adherence by pharmacy refill visits was significantly best in the category of patients who live 50-100 kilometers from the treatment sites.

Even though socio-economic status have been linked to HIV treatment outcomes [42-44], our study surprisingly did not suggest an association between socio-economic or behavioral predictors to virologic failure. The most important impact of SES on HIV treatment is on the cost of the HIV drugs, laboratory work-up and the commodities. Under PEPFAR, HIV drugs and commodities (nutrition, bed-nets, and laboratory tests) are free in Nigeria; SES does not determine access to drugs and services possibly accounting for the lack of association. This may change in coming years as donors push for more country ownership of programs like PEPFAR with a greater share of costs supported by the public sectors. Educational achievement, particularly post-secondary education which has been previously associated with positive treatment outcomes $[37,45]$ was associated with a $47 \%$ significantly reduced odds of virologic failure and $64 \%$ reduced odds of virologic discordance.

Immunologic failure normally occurs after virologic failure and can subsequently co-exist with each other. However, the associations of virologic and immunologic failure can differ since both conditions can also exist independently [46]. In our study, an increased odds of immunologic 
failure and immunologic discordance was associated with male gender. Male gender has been consistently associated with poor health seeking behaviors $[47,48]$, lower baseline CD4 count levels and poor HIV treatment outcomes $[37,49]$. This underlines again the necessity of making many health care facilities male-friendly and encouraging male peer-support systems as well as investing in research and programs that adequately engage males and seek to positively influence the health-seeking behavior of men.

Immuno-virologic discordance has been defined and studied in multiple settings mainly in resource-rich countries and has been associated with co-infections (especially Cytomegalovirus infections), age, lower baseline CD4 cell count, poor adherence and high mortality [15,50-52]. In our study, the presence of other viral infections were not tested and only age and educational achievement was associated with immuno-discordance and no associations were seen with tuberculosis history and baseline CD4 counts as expected. Unfortunately, tuberculosis history was not consistently obtained and objective screening tests were not routinely performed as indicated.

In addition, our study results strongly suggest that viral load testing should be incorporated into routine patient care, both at baseline and at least every 6 months. Without viral load results, $16 \%(n=90)$ of our study population would be switched to a second line ART regimen on the basis of their CD4 count results even though they had sustained viral suppression. Conversely, $17 \%(n=94)$ of our study population who were eligible for second line ART regimen would have continued on first line therapy inappropriately, also based on their CD4 count result only. This confirms the results of many studies that CD4 cell count alone is a poor predictor of virologic and clinical failure and an unreliable guide to appropriate clinical management of HIV infected patients on antiretroviral therapy [53-55]. Viral load and CD4 measurements when done together will help in further identifying and characterizing immuno-virologic discordance which has been associated with increased risk of AIDS events and mortality $[50,56]$. In the Development of Antiretroviral Therapy in Africa (DART) trial [57] which was done in a clinical trials setting unlike the current study, clinical monitoring alone had a $31 \%$ increase in disease progression and mortality compared to clinical monitoring with routine laboratory monitoring implying benefit albeit small associated with prompt switching to second-line therapy.

Limitations of this study include less than ideal follow-up time (12 months), issues with measurement error, missing data and possible administrative error in recording variables common in busy government hospitals in resource-constrained settings. We use unimputed data and assumed all missing variables were missing completely at random (MCAR) and confirmed this assumption by doing multiple imputations (using sequential regression multivariate imputation (SRMI) method) which produced similar results. There were no baseline HIV RNA viral load results and all patients are expected to have high viral loads at baseline. However, we expect patients fully adherent on potent HAART regimen to be undetectable at 12 months after commencement of therapy. This study was conducted in non-pregnant adults and may not be generalizable to pregnant women and children. This study has some unique strengths including its clinic-based cohort design with validated immunologic and virologic results even though viral load testing were not routinely performed in this program. The selection of different levels of care and different locations serving different populations improved the generalizability of our findings. In addition, since Tenofovir is not a common first line drug in ART programs in Africa, these results could provide additional information on programs that predominantly use this drug in low and middle income countries.

\section{Conclusion}

In summary, rapid HIV scale up has been hugely successful in Nigeria but challenges in patient retention and outcomes continue. With immuno-virologic outcomes known to worsen over time due to progressively poor adherence, pill fatigue and drug side effects, efforts should be intensified at baseline to identify patients who are likely to develop poor outcomes. Our study clearly shows that comprehensive baseline treatment preparation efforts needs to intensify adherence counseling, address anemia, male health seeking behavior, active case detection for opportunistic infections, affordable viral load testing, and regular CD4 cell count testing. In addition, younger patients (less than 30 years) and those with less than post-secondary education must receive priority attention in comprehensive treatment preparation and adherence support efforts. Future research efforts should be geared towards developing feasible and affordable routine viral load testing platforms and identifying whether operationalizing malaria and helminthiasis co-treatment will improve immuno-virologic outcomes. The role of sub-clinical or undiagnosed opportunistic infections in immuno-virologic discordance situations needs to be further evaluated.

\section{Endnote}

a This criterion was changed to CD4 count less than 350 cells / $\mathrm{ml}$ in 2010 in line with the WHO recommendation.

\section{Abbreviations}

3TC: Lamivudine; ABC: Abacavir; ADH: Asokoro District Hospital, Asokoro, Abuja; AIDS: Acquired Immunodeficiency Syndrome; ARV: Antiretroviral; ART: Antiretroviral therapy; AUROC: Area Under Receiver Operating Curve; 
UATH: University of Abuja Teaching Hospital, Gwagwalada; AZT: Azidothymidine / Zidovudine; BMI: Body mass index; CD4: Cluster of differentiation 4 T-helper cells; D4T: Stavudine; EFV: Efavirenz; FTC: Emtricitabine; Global Fund: Global Fund to fight AIDS, TB and Malaria; HAART: Highly active antiretroviral therapy; HACART Study: HIV AIDS Care and Antiretroviral Therapy study; HIV: Human immune-deficiency virus; IHV: Institute of Human Virology, Baltimore, Maryland; IHVN: Institute of Human Virology Nigeria; LPV/r: Lopinavir boosted with ritonavir; LTFU: Loss to follow-up; MAP: Multi-country AIDS Program of the World Bank; M\&E: Monitoring and Evaluation; MOHN: Ministry of Health, Nigeria; MTCT: Mother-to-child transmission of HIV; NHREC: Nigerian Health Research Ethics Committee; NNRTI: Non-nucleoside reverse transcriptase inhibitor; NRTI: Nucleoside reverse transcriptase inhibitor; NtRTI: Nucleotide reverse transcriptase inhibitor; NVP: Nevirapine; Ol: Opportunistic Infections; PEPFAR: President Emergency Fund for AIDS Relief; PI: Protease inhibitor; PLWHA: Persons living with HIV AIDS; PMM: Patient monitoring and management forms; TB: Tuberculosis; TDF: Tenofovir disoproxil fumarate; UBTH: University of Benin Teaching Hospital, Benin; UNAIDS: Joint United Nations Agency for AIDS; VL: HIV viral load; WHO: World Health Organization.

\section{Competing interests}

The authors declare that they have no competing interests.

\section{Authors' contributions}

Conceived and designed the study: CA, WB, CB, MC. Study implementation: CA, AA, EE, HO, SA, OA. Data analysis: CA, MC. Contributed reagents / materials / analysis tools: CA, AA, WB, MC. Wrote paper: CA. Reviewed paper: $C A, M C, C B, A A, M E, W B$. Supervised patient care: EE, $H O, S A, M E$. Coordinated ACTION project: WB, PD, MC, AA, ME. All authors read and approved the final manuscript.

\section{Acknowledgements}

We appreciate the President Emergency Plan for AIDS Relief (PEPFAR) for providing HIV care, treatment and support to the Nigerian people. We also thank all the study participants for taking part in this study and providing blood samples for laboratory testing. All the hospital staff and Institute of Human Virology staff who participated and supported the study are deeply appreciated.

\section{Funding}

The AIDS care and Treatment in Nigeria (ACTION) project is supported by the US Government Centers for Disease Control and Prevention Cooperative Agreement Number: PS000651. This publication is solely the responsibility of the authors and does not represent the official views of the CDC. Chuka Anude was funded by the US National Institutes of Health Fogarty AIDS International Training Research Program (AITRP, NIH 2-D43-TW001041-11).

\section{Financial disclosure}

The funders had no role in study design, data collection and analysis, decision to publish or preparation of the manuscript.

\section{Author details}

'Institute of Human Virology, University of Maryland School of Medicine, Baltimore, Maryland, USA. ${ }^{2}$ Johns Hopkins University Bloomberg School of Public Health, Baltimore, Maryland, USA. ${ }^{3}$ University of Benin Teaching Hospital, Benin City, Edo State, Nigeria. ${ }^{4}$ Asokoro District Hospital, Abuja, Federal Capital Territory, Abuja, Nigeria. ${ }^{5}$ University of Abuja Teaching Hospital, Abuja, Federal Capital Territory, Abuja, Nigeria. ${ }^{6}$ Institute of Human Virology Nigeria, Abuja, Nigeria.

Received: 3 April 2012 Accepted: 27 February 2013

Published: 1 March 2013

\section{References}

1. Apisarnthanarak $A$, et al: Antiretroviral drug resistance among antiretroviral-naive persons with recent HIV infection in Thailand. HIV Med 2008, 9(5):322-325.

2. Kitkungvan $D$, et al: Secure antiretroviral therapy delivery in a resourcelimited setting: streamlined to minimize drug resistance and expense. HIV Med 2008
3. Kamoto K, Aberle-Grasse J: Surveillance of transmitted HIV drug resistance with the World Health Organization threshold survey method in Lilongwe, Malawi. Antivir Ther 2008, 13(Suppl 2):83-7.

4. Wainberg MA: Two standards of care for HIV: why are Africans being short-changed? Retrovirology 2009, 6:109.

5. Gilks CF, et al: The WHO public-health approach to antiretroviral treatment against HIV in resource-limited settings. Lancet 2006, 368(9534):505-10.

6. Steele KT, et al: Early mortality and AIDS progression despite high initial antiretroviral therapy adherence and virologic suppression in botswana. PLoS One, 6(6):20010.

7. Keiser $\mathrm{O}$, et al: Outcomes of antiretroviral treatment in programmes with and without routine viral load monitoring in Southern Africa. Aids 2011, 25(14):1761-9.

8. Sungkanuparph $\mathrm{S}$, et al: Prevalence and risk factors for developing K65R mutations among HIV-1 infected patients who fail an initial regimen of fixed-dose combination of stavudine, lamivudine, and nevirapine. J Clin Virol 2008, 41(4):310-3.

9. Sungkanuparph $\mathrm{S}$, et al: Options for a second-line antiretroviral regimen for HIV type 1-infected patients whose initial regimen of a fixed-dose combination of stavudine, lamivudine, and nevirapine fails. Clin Infect Dis 2007, 44(3):447-52.

10. Ferradini $L$, et al: Scaling up of highly active antiretroviral therapy in a rural district of Malawi: an effectiveness assessment. Lancet 2006, 367(9519):1335-42.

11. Calmy A, et al: Generic fixed-dose combination antiretroviral treatment in resource-poor settings: multicentric observational cohort. AIDS 2006, 20(8):1163-9.

12. Laurent $C$, et al: The Senegalese government's highly active antiretroviral therapy initiative: an 18-month follow-up study. AIDS 2002, 16(10):1363-70.

13. WHO: Anti-retroviral therapy for HIV infection in adults and adolescents. revision: recommendations for a public health approach; 2010.

14. Loutfy MR, et al: CD4(+) cell count increase predicts clinical benefits in patients with advanced HIV disease and persistent viremia after 1 year of combination antiretroviral therapy. J Infect Dis 2005, 192(8):1407-11.

15. Tan R, et al: Clinical outcome of HIV-infected antiretroviral-naive patients with discordant immunologic and virologic responses to highly active antiretroviral therapy. J Acquir Immune Defic Syndr 2008, 47(5):553-8.

16. Maldonado G, Greenland S: Simulation study of confounder-selection strategies. Am J Epidemio/ 1993, 138(11):923-36.

17. Maldonado G, Greenland S: Interpreting model coefficients when the true model form is unknown. Epidemiology 1993, 4(4):310-8.

18. Smith DJ: Premarital sex, procreation, and HIV risk in Nigeria. Stud Fam Plann 2004, 35(4):223-35.

19. Djomand G, et al: Virologic and immunologic outcomes and programmatic challenges of an antiretroviral treatment pilot project in Abidjan, Cote d'Ivoire. AIDS 2003, 17(Suppl 3):S5-15.

20. Ramadhani $\mathrm{HO}$, et al: Predictors of incomplete adherence, virologic failure, and antiviral drug resistance among HIV-infected adults receiving antiretroviral therapy in Tanzania. Clin Infect Dis 2007, 45(11):8-1492.

21. Galdas PM, Cheater F, Marshall P: Men and health help-seeking behaviour: literature review. J Adv Nurs 2005, 49(6):23-616.

22. Taiwo BO, et al: Assessing the Viorologic and Adherence Benefits of PatientSelected HIV Treatment Partners in a Resource-limited. I Acquir Immune Defic Syndr: Setting; 2009.

23. Taiwo BO: Patient-selected treatment partners did not protect against drug resistance during first-line NNRTI-based HAART in a randomized trial. J Acquir Immune Defic Syndr. 54(5):5-563.

24. Isa SE: A prospective cohort study of immunologic and virologic outcomes in patients with HIV/AIDS and hepatitis virus co-infection in Jos, Nigeria. Niger J Med, 19(3):85-279.

25. Barth RE: Virological follow-up of adult patients in antiretroviral treatment programmes in sub-Saharan Africa: a systematic review. Lancet Infect Dis, 10(3):66-155.

26. Coetzee D, et al: Outcomes after two years of providing antiretroviral treatment in Khayelitsha, South Africa. AIDS 2004, 18(6):887-95.

27. Wester $\mathrm{CW}$, et al: Initial response to highly active antiretroviral therapy in HIV-1C-infected adults in a public sector treatment program in Botswana. J Acquir Immune Defic Syndr 2005, 40(3):336-43,

28. Gallant JE, et al: Tenofovir DF, emtricitabine, and efavirenz vs. zidovudine, lamivudine, and efavirenz for HIV. N Engl J Med 2006, 354(3):251-60. 
29. Gallant JE, et al: Efficacy and safety of tenofovir DF vs stavudine in combination therapy in antiretroviral-naive patients: a 3-year randomized trial. JAMA 2004, 292(2):191-201.

30. Pozniak $A L$, et al: Tenofovir disoproxil fumarate, emtricitabine, and efavirenz versus fixed-dose zidovudine/lamivudine and efavirenz in antiretroviral-naive patients: virologic, immunologic, and morphologic changes-a 96-week analysis. J Acquir Immune Defic Syndr 2006, 43(5):535-40.

31. Moore RD, Keruly JC, Chaisson RE: Anemia and survival in HIV infection. J Acquir Immune Defic Syndr Hum Retrovirol 1998, 19(1):29-33.

32. Toure $S$, et al: Rapid scaling-up of antiretroviral therapy in 10,000 adults in Cote d'Ivoire: 2-year outcomes and determinants. AIDS 2008, 22(7):873-82.

33. Dabis F, et al: Cohort Profile: Antiretroviral Therapy in Lower Income Countries (ART-LINC): international collaboration of treatment cohorts. Int J Epidemiol 2005, 34(5):979-86.

34. Smith JL, Brooker S: Impact of hookworm infection and deworming on anaemia in non-pregnant populations: a systematic review. Trop Med Int Health 2010, 15(7):776-95.

35. Glass TR, et al: Correlates of self-reported nonadherence to antiretroviral therapy in HIV-infected patients: the Swiss HIV Cohort Study. J Acquir Immune Defic Syndr 2006, 41(3):385-92.

36. Gordillo $\vee$, et al: Sociodemographic and psychological variables influencing adherence to antiretroviral therapy. AIDS 1999, 13(13):1763-9.

37. Charurat $M$, et al: Patient retention and adherence to antiretrovirals in a large antiretroviral therapy program in Nigeria: a longitudinal analysis for risk factors. PLoS One, 5(5):10584.

38. Pettifor A, et al: Early coital debut and associated HIV risk factors among young women and men in South Africa. Int Perspect Sex Reprod Health 2009, 35(2):82-90.

39. Speizer IS, et al: Sexual violence and reproductive health outcomes among South African female youths: a contextual analysis. Am J Public Health 2009, 99(Suppl 2):S425-31.

40. Kaestle $C E$, et al: Young age at first sexual intercourse and sexually transmitted infections in adolescents and young adults. Am J Epidemiol 2005, 161(8):774-80.

41. Posse $M$, et al: Barriers to access to antiretroviral treatment in developing countries: a review. Trop Med Int Health 2008, 13(7):904-13.

42. Koenig SP, Leandre F, Farmer PE: Scaling-up HIV treatment programmes in resource-limited settings: the rural Haiti experience. AIDS 2004, 18 (Suppl 3):S21-5.

43. van Oosterhout JJ, et al: Evaluation of antiretroviral therapy results in a resource-poor setting in Blantyre, Malawi. Trop Med Int Health 2005, 10(5):464-70.

44. Bhat VG, et al: Factors associated with poor adherence to anti-retroviral therapy in patients attending a rural health centre in South Africa. Eur J Clin Microbiol Infect Dis, 29(8):-53-947.

45. Marc LG, et al: Educational attainment and response to HAART during initial therapy for HIV-1 infection. J Psychosom Res 2007, 63(2):207-16.

46. Grabar $S$, et al: Clinical outcome of patients with HIV-1 infection according to immunologic and virologic response after 6 months of highly active antiretroviral therapy. Ann Intern Med 2000, 133(6):401-10.

47. Keiser O, et al: Antiretroviral therapy in resource-limited settings. to 2006: patient characteristics, treatment regimens and monitoring in subSaharan Africa, Asia and Latin America. Trop Med Int Health, 2008 1996, 13(7):9-870

48. Braitstein $P$, et al: Gender and the use of antiretroviral treatment in resource-constrained settings: findings from a multicenter collaboration. J Womens Health (Larchmt) 2008, 17(1):47-55.

49. Nash $D$, et al: Long-term immunologic response to antiretroviral therapy in low-income countries: a collaborative analysis of prospective studies AIDS 2008, 22(17):2291-302.

50. Moore DM, et al: Discordant immunologic and virologic responses to highly active antiretroviral therapy are associated with increased mortality and poor adherence to therapy. J Acquir Immune Defic Syndr 2005, 40(3):288-93.

51. Goossens VJ, et al: A delay in CD4 cell response after initiation of highly active antiretroviral therapy is associated with the presence of anticytomegalovirus but not with anti-herpes simplex virus antibodies. Aids 2002, 16(12):1682-4.
52. Gilson RJ, et al: Discordant responses on starting highly active antiretroviral therapy: suboptimal CD4 increases despite early viral suppression in the UK Collaborative HIV Cohort (UK CHIC) Study. HIV Med, 11(2):60-152.

53. Badri M, Lawn SD, Wood R: Utility of CD4 cell counts for early prediction of virological failure during antiretroviral therapy in a resource-limited setting. BMC Infect Dis 2008, 8:89.

54. Lundgren JD, et al: Inferior clinical outcome of the CD4+ cell countguided antiretroviral treatment interruption strategy in the SMART study: role of CD4+ Cell counts and HIV RNA levels during follow-up. $J$ Infect Dis 2008, 197(8):1145-55.

55. Kantor $\mathrm{R}$, et al: Misclassification of first-line antiretroviral treatment failure based on immunological monitoring of HIV infection in resource-limited settings. Clin Infect Dis 2009, 49(3):454-62.

56. Zoufaly A, et al: Clinical outcome of HIV-infected patients with discordant virological and immunological response to antiretroviral therapy. J Infect Dis 2011, 203(3):364-71.

57. Mugyenyi $P$, et al: Routine versus clinically driven laboratory monitoring of HIV antiretroviral therapy in Africa (DART): a randomised non-inferiority trial. Lancet, 375(9709):31-123.

doi:10.1186/1471-2334-13-113

Cite this article as: Anude et al:: Immuno-virologic outcomes and immuno-virologic discordance among adults alive and on anti-retroviral therapy at 12 months in Nigeria. BMC Infectious Diseases 2013 13:113.

\section{Submit your next manuscript to BioMed Central and take full advantage of:}

- Convenient online submission

- Thorough peer review

- No space constraints or color figure charges

- Immediate publication on acceptance

- Inclusion in PubMed, CAS, Scopus and Google Scholar

- Research which is freely available for redistribution 